\title{
Description of Gluconacetobacter swingsii sp. nov. and Gluconacetobacter rhaeticus sp. nov., isolated from Italian apple fruit
}

Correspondence

Franco Dellaglio

franco.dellaglio@univr.it

\author{
Franco Dellaglio, ${ }^{1}$ Ilse Cleenwerck, ${ }^{2}$ Giovanna E. Felis, ${ }^{1}$ \\ Katrien Engelbeen, ${ }^{2}$ Danielle Janssens ${ }^{2}$ and Marta Marzotto ${ }^{1}$ \\ ${ }^{1}$ Science and Technology Department, University of Verona, Strada le Grazie, 15, 37134 \\ Verona, Italy \\ ${ }^{2}$ BCCM/LMG Bacteria Collection, Laboratory of Microbiology, Ghent University, \\ K.L. Ledeganckstraat 35, B-9000 Ghent, Belgium
}

Species of the genus Gluconacetobacter can be phylogenetically subgrouped into two clusters: ' $\mathrm{N}_{2}$-fixing' (Gluconacetobacter diazotrophicus, Gluconacetobacter liquefaciens, Gluconacetobacter sacchari, Gluconacetobacter azotocaptans and Gluconacetobacter johannae) and 'cellulose-producing' (Gluconacetobacter xylinus, Gluconacetobacter europaeus, Gluconacetobacter intermedius, Gluconacetobacter oboediens, Gluconacetobacter hansenii and Gluconacetobacter entanii). Characterization of a new isolate on the basis of these phenotypic traits might, however, lead to an erroneous identification, as each cluster contains strains lacking these properties (Bernardo et al., 1998; Franke et al., 1999; Fuentes-Ramirez et al., 2001). For instance, the ability to synthesize cellulose is easily lost in many strains and cannot be used as a determinative feature (Swings, 1992).

The species belonging to this genus, most of which have been proposed since 1998 (Boesch et al., 1998; Sokollek et al., 1998; Franke et al., 1999; Schüller et al., 2000; Yamada, 2000;

The GenBank/EMBL/DDBJ accession numbers for the 16S rRNA gene sequences of Gluconacetobacter swingsii DST GLO1 ${ }^{\top}$ and Gluconacetobacter rhaeticus DST GLO2 $^{\top}$ are AY180960 and AY180961, respectively.

Tables of DNA-DNA hybridization data and additional distinguishing characteristics are available as supplementary material in IJSEM Online.
Fuentes-Ramirez et al., 2001), are strongly correlated at the phylogenetic level.

In this study we present a comprehensive taxonomic analysis of two cellulose-producing strains of acetic acid bacteria (DST GL01 ${ }^{\mathrm{T}}$ and DST GL02 ${ }^{\mathrm{T}}$ ), isolated from apple fruit juice in the South Tyrol region of Italy (Val Venosta), by means of the study of phenotypic and chemotaxonomic properties, the analysis of the phylogenetic marker $16 \mathrm{~S}$ rRNA gene, the DNA base composition and DNA relatedness. We provide evidence that the two new isolates represent two different new cellulose-producing species within the genus Gluconacetobacter, for which we propose the names Gluconacetobacter swingsii sp. nov. and Gluconacetobacter rhaeticus sp. nov.

Two cellulose-producing strains, DST GL01 ${ }^{\mathrm{T}}$ and DST $\mathrm{GL}^{\mathrm{T}}{ }^{\mathrm{T}}$, were isolated from organic apple juice prepared with fruits from the Val Venosta region in Italy. Both strains were propagated in liquid culture without shaking, using the synthetic medium ACE ( $50 \mathrm{~g}$ glucose $1^{-1}, 5 \mathrm{~g}$ yeast extract $\left.1^{-1}, \mathrm{pH} 6.5\right)$ and incubated aerobically at $28^{\circ} \mathrm{C}$ for 6 days. The isolation and identification of superoxidizing acetic acid bacteria were performed in Medium 2 (30 g yeast extract $\mathrm{l}^{-1}, 0 \cdot 22 \mathrm{~g}$ bromocresol green $\mathrm{l}^{-1}, 2 \%, \mathrm{v} / \mathrm{v}$, ethanol, $15 \mathrm{~g}$ agar $\left.1^{-1}, \mathrm{pH} 6 \cdot 5\right)$. The colonies showed a yellow 
acidification halo that turns to blue after acetic acid superoxidation to $\mathrm{CO}_{2}$ and $\mathrm{H}_{2} \mathrm{O}$, indicating that they belonged to Acetobacter/Gluconacetobacter and not to Gluconobacter (Swings, 1992). Cell shape and cell size were determined from cells grown aerobically at $28^{\circ} \mathrm{C}$ for 3 days on ACE agar medium. Gram staining, oxidase and catalase activity were determined as described previously (Cleenwerck et al., 2002). Cells of DST GL01 ${ }^{\mathrm{T}}$ and DST GL02 ${ }^{\mathrm{T}}$ were Gramnegative, non-motile coccoid rods. Both isolates were catalase-positive and oxidase-negative.

DNA for PCR amplification was isolated from celluloseproducing cultures $(10 \mathrm{ml})$, preliminarily homogenized by an UltraTurrax T25 (IKA) at 8500 r.p.m. for $15 \mathrm{~s}$ and filtered through sterile gauzes to eliminate the polysaccharide matrix. Cells were collected by centrifugation, washed three times, resuspended in $0.5 \mathrm{ml}$ TE buffer ( $\mathrm{pH} 8 \cdot 0$ ), supplemented with $10 \mathrm{~g}$ lysozyme $1^{-1}$, and incubated at $37^{\circ} \mathrm{C}$ for $2 \mathrm{~h}$. The DNA was isolated by the CTAB method (Cleenwerck et al., 2002). PCR amplification of the $16 \mathrm{~S}$ rRNA genes was conducted as described by Boesch et al. (1998). Amplification products were purified from a $1 \%$ (w/v) agarose gel by the QIAEX II Gel Extraction System (Qiagen). Sequencing was carried out on purified PCR amplicons at the Bio Molecular Research Center (BMR), University of Padua, Italy. The 16S rRNA gene sequences determined and sequences of strains belonging to the same phylogenetic group, retrieved from the EMBL library, were aligned and a phylogenetic tree was constructed by the neighbour-joining method using the BioNumerics 3.50 software package (Applied Maths). Unknown bases were discarded from the calculations. Bootstrapping analysis was undertaken to test the statistical reliability of the topology of the neighbour-joining tree using 1000 bootstrap resamplings of the data. A maximum-parsimony analysis was also performed with the program DNAPARS of the PHYLIP package (version 3.5c), using the default options. Sequence similarity calculations after a neighbour-joining analysis showed that the nearly complete $16 \mathrm{~S}$ rRNA gene sequences of DST GLO1 $1^{\mathrm{T}}$ and DST GL02 ${ }^{\mathrm{T}}$ (1446 and $1336 \mathrm{bp}$, respectively) had the highest similarities to sequences of reference strains of the G. xylinus branch (98.5-100\%). The levels of similarity to the $16 \mathrm{~S}$ rRNA genes of other validly described species of the Acetobacteraceae family were below $97 \cdot 2 \%$. A neighbour-joining tree, reflecting the positions of these strains within the acetic acid bacteria lineage, is shown in Fig. 1. Parsimony analysis confirmed the phylogenetic placement of the strains in the 'cellulose-producing' Gluconacetobacter species cluster.

Analyses of respiratory quinones were carried out by the Identification Service of the DSMZ and Dr Brian Tindall, Braunschweig, Germany. Respiratory lipoquinones were determined from cells grown on Sabouraud-glucose (2\%)

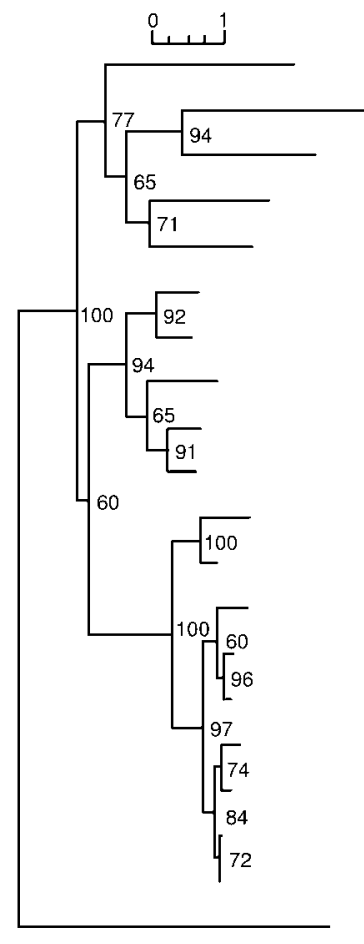

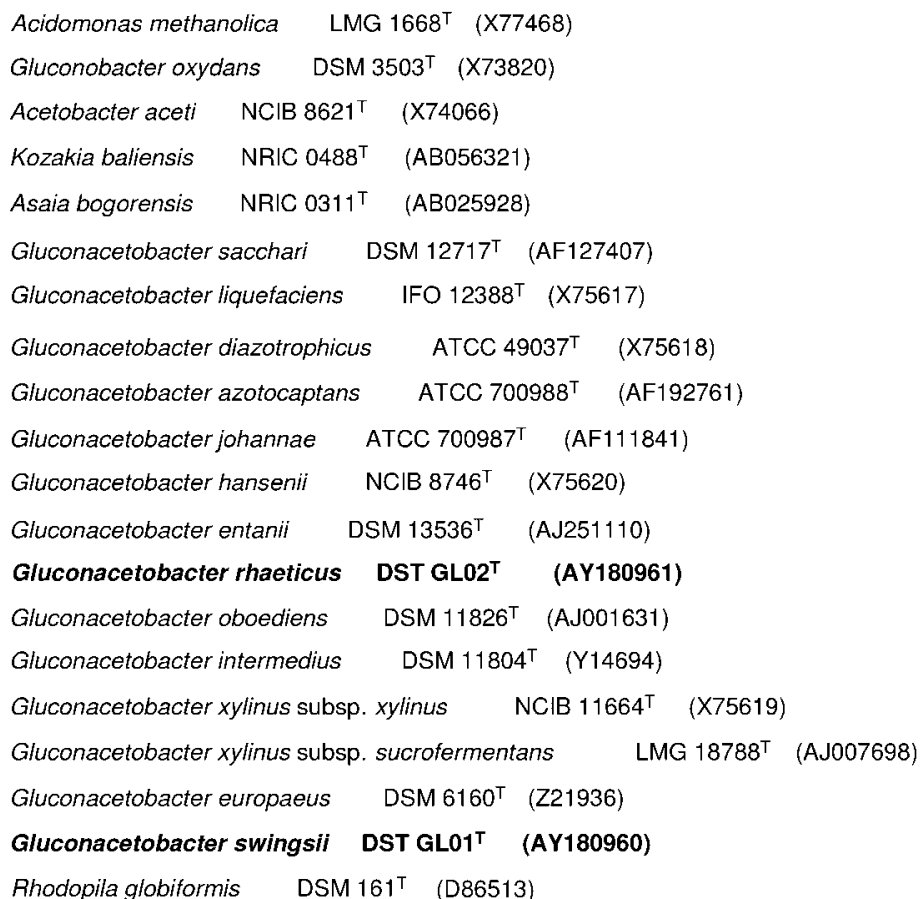

Fig. 1. Phylogenetic tree obtained by neighbour-joining analysis of the almost complete $16 \mathrm{~S}$ rRNA gene sequences, showing the positions of Gluconacetobacter swingsii DST GL01 ${ }^{\top}$ and Gluconacetobacter rhaeticus DST GL02 ${ }^{\top}$ within the acetic acid bacteria. Rhodopila globiformis DSM $161^{\top}$ was used as outgroup in the analysis. Bar, $1 \%$ sequence dissimilarity. Numbers at branching points indicate bootstrap percentages derived from 1000 samples. Accession numbers are given in parentheses. 
liquid medium, pH $5 \cdot 7$, at $29^{\circ} \mathrm{C}$. The respiratory lipoquinones were extracted from $100 \mathrm{mg}$ freeze-dried cell material based on the two-stage method described by Tindall (1990a, b) using methanol:hexane. They were separated into their different classes (menaquinones and ubiquinones) by thin layer chromatography on silica gel (Art. NO. 805 023; Macherey-Nagel), using hexane : tert-butylmethylether $(9: 1, \mathrm{v} / \mathrm{v})$ as solvent. UV absorbing bands corresponding to menaquinones or ubiquinones were removed from the plate and further analysed on an LDC Analytical (Thermo Separation Products) HPLC fitted with a reverse phase column $(2 \times 125 \mathrm{~mm}, 3 \mu \mathrm{m}$ particle size, RP18; MachereyNagel) using methanol as the eluant. Respiratory lipoquinones were detected at $269 \mathrm{~nm}$. DST GL01 ${ }^{\mathrm{T}}$ and DST GL02 ${ }^{\mathrm{T}}$ contained Q-10 as the major component, a characteristic that is common to strains belonging to the genus Gluconacetobacter (Yamada, 2000).

Fatty acid profiles were determined from cells grown for $48 \mathrm{~h}$ at $28^{\circ} \mathrm{C}$ under aerobic conditions on M129 medium from the Catalogue of Cultures of the BCCM/LMG Bacteria Collection (Janssens et al., 1998), containing 5.0\% Dglucose, $0 \cdot 5 \%$ yeast extract and $1 \cdot 5 \%$ agar (final $\mathrm{pH} 6 \cdot 5$ ). Fatty acids were prepared and identified following the instructions of the MIDI (Microbial Identification) system. DST GLO1 $1^{\mathrm{T}}$ and DST GL02 ${ }^{\mathrm{T}}$ contained large amounts of the fatty acid $\mathrm{C}_{18: 1 \omega 7 \mathrm{c}}$ (approx. $50 \%$ of the fatty acid content). The other fatty acids found in smaller but still significant amounts were $\mathrm{C}_{16: 0}(13 \cdot 1 \%), \mathrm{C}_{17: 0}(9 \cdot 8 \%)$ and $2-\mathrm{OH}$ $\mathrm{C}_{16: 0}(6 \cdot 6 \%)$ for DST GL01 ${ }^{\mathrm{T}}$, and 2-OH C $\mathrm{C}_{14: 0}(19 \cdot 5 \%), 2-$ $\mathrm{OH} \mathrm{C}_{16: 0}(16 \cdot 5 \%)$ and $\mathrm{C}_{16: 0}(6 \cdot 9 \%)$ for DST GL02 ${ }^{\mathrm{T}}$. These results are comparable to the results obtained for other Gluconacetobacter species (Urakami et al., 1989; Franke et al., 1999).

DST GL $01^{\mathrm{T}}$ and DST GLO2 ${ }^{\mathrm{T}}$ were hybridized with the type strains of the 'cellulose-producing' Gluconacetobacter species: G. oboediens LMG $18849^{\mathrm{T}}$, G. intermedius LMG $18909^{\mathrm{T}}$, G. europaeus LMG $18890^{\mathrm{T}}$, G. xylinus subsp. xylinus LMG $1515^{\mathrm{T}}$, G. xylinus subsp. sucrofermentans LMG $18788^{\mathrm{T}}$, G. hansenii LMG $1527^{\mathrm{T}}$ and G. entanii LTH $4560^{\mathrm{T}}$. Highmolecular-mass DNA for the DNA-DNA hybridization study was prepared by the method of Wilson (1987), with minor modifications (Cleenwerck et al., 2002). The type strains were cultured as recommended by the BCCM/LMG Bacteria Collection, except for $G$. entanii for which a pellet of cells was kindly supplied to us by Dr Hertel (University of Hohenheim, Germany). Strains LMG $18909^{\mathrm{T}}$, LMG $1515^{\mathrm{T}}$ and DST GLO2 $2^{\mathrm{T}}$ were subjected to a mild alkaline hydrolysis step before cell lysis, as described by Willems et al. (2001). DNA quantity and quality were determined by measuring absorption at 260, 280 and $234 \mathrm{~nm}$. Only high quality DNA with $A_{260} / A_{280}$ and $A_{234} / A_{260}$ ratios of $1 \cdot 8-2 \cdot 0$ and $0 \cdot 40$ $0 \cdot 60$, respectively, was selected for further use. The size of the DNA was estimated by agarose gel electrophoresis. Only high-molecular-mass DNA was used. DNA-DNA hybridizations were performed using a modification of the microplate method described by Ezaki et al. (1989) (Goris et al.,
1998; Cleenwerck et al., 2002). The hybridization temperature was $48{ }^{\circ} \mathrm{C}$. Reciprocal reactions (e.g. $\mathrm{A} \times \mathrm{B}$ and $\mathrm{B} \times \mathrm{A}$ ) were performed. The DNA-binding values reported are the mean values of a minimum of four hybridization experiments, the reciprocal reactions included. The level of DNA-DNA binding between DST GL01 ${ }^{\mathrm{T}}$ and DST GL02 ${ }^{\mathrm{T}}$ $(45 \%)$ and between these strains and the type strains of the G. xylinus branch $(\leqslant 60 \%)$ demonstrates a relatedness below the species level.

In this study the DNA-DNA binding values between the type strains of the G. xylinus branch were also determined (except for G. entanii for which it is very difficult to obtain enough DNA for hybridizations) to obtain a clear view of the DNA relatedness between these strains (see Supplementary Table A in IJSEM Online). From the current literature data, this was not really possible due to multiple factors. The reported DNA binding values are difficult to compare with each other as in many cases different DNA hybridization methods were used. DNA-binding values between some of these species are only vaguely reported, such as the DNA-binding values between $G$. intermedius and G. xylinus and between G. intermedius and G. hansenii (DNA-binding values are below $60 \%$ ). But most of all, DNA-binding values between some species have not been reported, such as those between G. oboediens and $G$. intermedius, G. oboediens and G. hansenii, G. entanii and G. intermedius. The DNA-binding value between $G$. intermedius and G. europaeus (57\%) is comparable to the $60 \%$ reported by Boesch et al. (1998). The values between $G$. oboediens and G. intermedius (63\%), and between $G$. oboediens and $G$. hansenii (24\%) demonstrate that they represent different species. The DNA-binding values between G. oboediens and G. xylinus (68\%), and between G. oboediens and G. europaeus (51\%) are higher than the values reported by Sokollek et al. (1998) (34 and 25\%, respectively). The discrepancy between these data are probably due to the fact that Sokollek et al. (1998) did not perform reciprocal reactions, which are very important to obtain unequivocal results. The DNA homology value between G. xylinus subsp. xylinus and G. xylinus subsp. sucrofermentans $(56 \%)$ is comparable to the $58 \cdot 2 \%$ reported by Toyosaki et al. (1995). This value is lower than DNA-binding values found between some other species in the G. xylinus branch and therefore the question could be raised whether G. xylinus subsp. sucrofermentans should be elevated to the species level.

The G $+\mathrm{C}$ content of DST GL01 ${ }^{\mathrm{T}}(61 \cdot 7 \mathrm{~mol} \%)$ and DST GL02 $^{\mathrm{T}}(63 \cdot 4 \mathrm{~mol} \%)$ was determined by HPLC according to the method of Mesbah et al. (1989). Non-methylated phage $\lambda$ DNA (Sigma) was used as the calibration reference.

Phenotypic characterization of DST GL01 ${ }^{\mathrm{T}}$ and DST GL02 ${ }^{\mathrm{T}}$ was performed. The production of 2- and 5-keto-D-gluconic acid was determined by the method described by Gosselé et al. (1980). Tolerance to $3 \%(\mathrm{v} / \mathrm{v})$ ethanol was tested in acid medium ( $5 \mathrm{~g}$ yeast extract $\mathrm{l}^{-1}, \mathrm{pH} 3 \cdot 0$ ). The ability to grow on different carbon sources was tested using a 
standardized and miniaturized assimilation test, ID 32C (Biomérieux), following the manufacturer's guidelines, using bacterial suspensions with an $\mathrm{OD}_{600}$ of $0 \cdot 7$ to inoculate the galleries. The composition of the minimal medium and the carbon substrates tested are reported in the protocol from the kit. The ability to grow on different carbon sources was determined after 15 days incubation at $28^{\circ} \mathrm{C}$. Cellulose production was tested in the presence of $1 \%(\mathrm{w} / \mathrm{v})$ D-glucose, $1 \%(\mathrm{w} / \mathrm{v})$ D-fructose, $1 \%(\mathrm{w} / \mathrm{v})$ sucrose, $2 \%(\mathrm{w} / \mathrm{v})$ ethanol and $2 \%(\mathrm{v} / \mathrm{v})$ glycerol in a liquid medium containing $5 \mathrm{~g}$ yeast extract $\mathrm{l}^{-1}$. The phenotypic characteristics of DST GL01 ${ }^{\mathrm{T}}$ and DST $\mathrm{GL} 02^{\mathrm{T}}$ are given in the species descriptions below. The characteristics that differentiate the two strains from each other and from their phylogenetically closest neighbours are given in Table 1 (additional characteristics differentiating DST $\mathrm{GLO1}^{\mathrm{T}}$ from DST GL02 ${ }^{\mathrm{T}}$ are available in Supplementary Table B in IJSEM Online). DST GL $01^{\mathrm{T}}$ is distinguished from G. xylinus by the ability to grow on $3 \%$ ethanol in the presence of $4-8 \%$ acetic acid, the ability to grow on ethanol as carbon source and the ability to grow in the presence of $30 \%$ D-glucose. It is distinguished from G. europaeus by the ability to grow in the absence of acetic acid, the ability to grow on ethanol, sucrose, sorbitol, D-mannitol and Dgluconate as carbon sources and the inability to grow on D-ribose as carbon source. DST GL02 ${ }^{\mathrm{T}}$ is distinguished from G. oboediens by the ability to produce 5-keto-D-gluconic acid from D-glucose, the ability to grow on ethanol,
D-xylose, sorbitol and D-mannitol as carbon sources and the inability to grow on D-gluconate as carbon source. It is distinguished from $G$. intermedius by the ability to produce 2- and 5-keto-D-gluconic acid from D-glucose. DST GL01 ${ }^{\mathrm{T}}$ and DST $\mathrm{GLO}^{\mathrm{T}}$ did not grow in liquid medium shaken on a rotary shaker. Cell proliferation seems to be strictly correlated to cellulose production (Kamide et al., 1990).

Overall, the results obtained indicate that DST GL01 ${ }^{\mathrm{T}}$ and DST GL02 ${ }^{\mathrm{T}}$ represent two novel species of the genus Gluconacetobacter, for which we propose the names Gluconacetobacter swingsii sp. nov. and Gluconacetobacter rhaeticus sp. nov., respectively.

\section{Description of Gluconacetobacter swingsii sp. nov.}

Gluconacetobacter swingsii (swing'si.i. N.L. gen. n. swingsii of Swings, in honour of Jean Swings who studied and reviewed acetic acid bacteria).

Cells are Gram-negative, coccoid, approximately $0.9 \times 1 \cdot 5$ $2.5 \mu \mathrm{m}$ in size, occurring singly or in pairs. Cells are nonmotile. Endospores are not detected. Colonies are beige, regular, convex and smooth with a diameter of $0.8 \mathrm{~mm}$ on standard medium. Oxidase-negative. Catalase-positive. DGlucose is oxidized to 2- and 5- keto-D-gluconic acid. Acetic acid is not required for growth. Growth is observed in $3 \%$ $(\mathrm{v} / \mathrm{v})$ ethanol in acid medium, $\mathrm{pH} 3 \cdot 0$. Growth occurs on

Table 1. Characteristics differentiating G. swingsii sp. nov. and G. rhaeticus sp. nov. from each other and from the phylogenetically closely related Gluconacetobacter species

Species: 1, G. swingsii; 2, G. rhaeticus; 3, G. oboediens (data from Sokollek et al., 1998); 4, G. intermedius (data from Boesch et al., 1998); 5, G. xylinus (data from Sokollek et al., 1998); 6, G. europaeus (data from Sokollek et al., 1998); 7, G. hansenii [data from Gosselé et al. (1983) and Navarro et al. (1999)]; 8, G. entanii (data from Schüller et al., 2000). Symbols: +, positive; -, negative; V, variable; NR, not reported.

\begin{tabular}{|c|c|c|c|c|c|c|c|c|}
\hline Character & 1 & 2 & 3 & 4 & 5 & 6 & 7 & 8 \\
\hline \multicolumn{9}{|l|}{ Production of keto-D-gluconates from D-glucose: } \\
\hline 2-Keto-D-gluconate & + & + & + & - & + & NR & + & - \\
\hline 5-Keto-D-gluconate & + & + & - & - & + & $\mathrm{NR}$ & + & - \\
\hline Growth without acetic acid & + & + & + & + & + & - & + & - \\
\hline $\begin{array}{l}\text { Growth on } 3 \% \text { ethanol in the presence of } 4-8 \% \\
\text { acetic acid }\end{array}$ & + & + & + & NR & - & + & - & + \\
\hline \multicolumn{9}{|l|}{ Growth on carbon sources: } \\
\hline Ethanol & + & + & - & NR & - & - & - & NR \\
\hline D-Fructose & + & + & + & NR & + & + & $\mathrm{v}$ & + \\
\hline Maltose & + & + & + & NR & + & + & $\mathrm{v}$ & + \\
\hline D-Ribose & - & + & + & NR & - & + & - & NR \\
\hline D-Xylose & + & + & - & NR & + & + & - & NR \\
\hline Sucrose & + & + & + & NR & + & - & $\mathrm{V}$ & + \\
\hline Sorbitol & + & + & - & NR & + & - & - & - \\
\hline D-Mannitol & + & + & - & NR & + & - & $\mathrm{V}$ & - \\
\hline D-Gluconate & + & - & + & NR & + & - & - & - \\
\hline Growth in the presence of $30 \% \mathrm{D}$-glucose & + & + & + & NR & - & - & - & - \\
\hline
\end{tabular}


cellobiose, D-xylose, maltose, D-mannitol, melezitose, raffinose, sorbitol, sorbose, trehalose, D-gluconate, glucuronate and glucosamine as carbon sources, but not on erythritol, galactose, L-arabinose, melibiose, palatinose, rhamnose and D-ribose. Cellulose is produced from glucose, ethanol and glycerol, but not from fructose and sucrose. The ubiquinone system consists of Q-10 as the major component and Q-9 as a minor component. $\mathrm{C}_{18: 1 \omega 7 c}$ is the major fatty acid (50\%); other fatty acids in smaller but still significant amounts are $\mathrm{C}_{16: 0}(13 \cdot 1 \%), \mathrm{C}_{17: 0}(9 \cdot 8 \%)$ and $2-\mathrm{OH} \mathrm{C} \mathrm{C}_{16: 0}(6 \cdot 6 \%)$. The DNA G $+\mathrm{C}$ content of the type strain is $61.7 \mathrm{~mol} \%$. Isolated from apple juice in South Tyrol region, Italy. Type strain is DST $\mathrm{GL}^{\mathrm{T}}{ }^{\mathrm{T}}$ ( $=\mathrm{LMG}$ $22125^{\mathrm{T}}=$ DSM $16373^{\mathrm{T}}$ ).

\section{Description of Gluconacetobacter rhaeticus sp. nov.}

Gluconacetobacter rhaeticus (rhae'ti.cus. L. masc. adj. rhaeticus pertaining to Rhaetia, Latin denomination of South Tyrol region in Italy, where the type strain was isolated).

Cells are Gram-negative, coccoid, approximately $0 \cdot 9 \times 1 \cdot 5-$ $2.5 \mu \mathrm{m}$ in size, occurring singly, in pairs or in short chains. Cells are non-motile. Endospores are not detected. Colonies are beige, regular, convex and weakly rough with a diameter of $1.0 \mathrm{~mm}$ on standard medium. Oxidase-negative. Catalase-positive. D-Glucose is oxidized to 2- and 5-keto-Dgluconic acid. Acetic acid is not required for growth. Growth is observed in $3 \%(\mathrm{v} / \mathrm{v})$ ethanol in acid medium, $\mathrm{pH} 3 \cdot 0$. Growth occurs on cellobiose, D-xylose, maltose, D-mannitol, melezitose, raffinose, sorbitol, sorbose, trehalose, erythritol, galactose, L-arabinose, melibiose, palatinose, rhamnose and D-ribose as carbon sources, but not on D-gluconate, glucuronate and glucosamine. Cellulose is produced from glucose, ethanol, glycerol, fructose and sucrose. The ubiquinone system consists of Q-10 components. $\mathrm{C}_{18: 1 \omega 7 c}$ is the major fatty acid (50\%); other fatty acids in smaller but still significant amounts are $2-\mathrm{OH}$ $\mathrm{C}_{14: 0}(19 \cdot 5 \%), 2-\mathrm{OH} \mathrm{C}_{16: 0}(16 \cdot 5 \%)$ and $\mathrm{C}_{16: 0}(6 \cdot 9 \%)$. The DNA G + C content of the type strain is $63 \cdot 4 \mathrm{~mol} \%$. Isolated from apple juice in South Tyrol region, Italy. Type strain is DST GL02 ${ }^{\mathrm{T}}\left(=\mathrm{LMG} 22126^{\mathrm{T}}=\mathrm{DSM} 16663^{\mathrm{T}}\right)$.

\section{Acknowledgements}

This research was supported by the Prime Minister's Services - Federal Office for Scientific, Technical and Cultural Affairs, Belgium.

\section{References}

Bernardo, E. B., Neilan, B. A. \& Couperwhite, I. (1998). Characterization, differentiation and identification of wild-type cellulose-synthesizing Acetobacter strains involved in Nata de Coco production. Syst Appl Microbiol 21, 599-608.

Boesch, C., Trcek, J., Sievers, M. \& Teuber, M. (1998). Acetobacter intermedius, sp. nov. Syst Appl Microbiol 21, 220-229.
Cleenwerck, I., Vandemeulebroecke, K., Janssens, D. \& Swings, J. (2002). Re-examination of the genus Acetobacter, with descriptions of Acetobacter cerevisiae sp. nov. and Acetobacter malorum sp. nov. Int J Syst Evol Microbiol 52, 1551-1558.

Ezaki, T., Hashimoto, Y. \& Yabuuchi, E. (1989). Fluorometric deoxyribonucleic acid-deoxyribonucleic acid hybridization in microdilution wells as an alternative to membrane filter hybridization in which radioisotopes are used to determine genetic relatedness among bacterial strains. Int J Syst Bacteriol 39, 224-229.

Franke, I. H., Fegan, M., Hayward, C., Leonard, G., Stackebrandt, E. \& Sly, L. I. (1999). Description of Gluconacetobacter sacchari sp. nov., a new species of acetic acid bacterium from the leaf sheath of sugar cane and from the pink sugar-cane mealy bug. Int J Syst Bacteriol 49, 1681-1693.

Fuentes-Ramirez, L. E., Bustillos-Cristales, R., Tapia-Hernandez, A., Jimenez-Salgado, T., Wang, E. T., Martinez-Romero, E. \& Caballero-Mellado, J. (2001). Novel nitrogen-fixing acetic acid bacteria, Gluconacetobacter johannae sp. nov. and Gluconacetobacter azotocaptans sp. nov., associated with coffee plants. Int J Syst Evol Microbiol 51, 1305-1314.

Goris, J., Suzuki, K., De Vos, P., Nakase, T. \& Kersters, K. (1998). Evaluation of a microplate DNA-DNA hybridization method compared with the initial renaturation method. Can J Microbiol 44, 1148-1153.

Gosselé, F., Swings, J. \& De Ley, J. (1980). A rapid, simple and simultaneous detection of 2-keto, 5-keto- and 2,5-diketogluconic acids by thin-layer chromatography in culture media of acetic acid bacteria. Zentralbl Bakteriol Parasitenkd Infektionskr Hyg Abt I Orig Reihe C1, 178-181.

Gosselé, F., Swings, J., Kesters, K., Pauwels, P. \& De Ley, J. (1983). Numerical analysis of phenotypic features and protein gel electropherograms of a wide variety of Acetobacter strains. Proposal for the improvement of the taxonomy of the genus Acetobacter Beijerinck 1898. Syst Appl Microbiol 4, 338-368.

Janssens, D., Vereecke, C., Vanhonacker, K. \& 7 other editors (1998). BCCM/LMG Catalogue Bacteria 1998. Belgian Coordinated Collections of Micro-organisms, Belgian Federal Office for Scientific, Technical and Cultural Affairs.

Kamide, K., Matsuda, Y., lijima, H. \& Okajima, K. (1990). Effect of culture conditions of acetic acid bacteria on cellulose biosynthesis. $\mathrm{Br}$ Polym J 22, 167-171.

Mesbah, M., Premachandran, U. \& Whitman, W. B. (1989). Precise measurement of the $\mathrm{G}+\mathrm{C}$ content of deoxyribonucleic acid by highperformance liquid chromatography. Int J Syst Bacteriol 39, 159-167.

Navarro, R., Uchimura, T. \& Komagata, K. (1999). Taxonomic heterogeneity of strains comprising Gluconacetobacter hansenii. J Gen Appl Microbiol 45, 295-300.

Schüller, G., Hertel, C. \& Hammes, W. P. (2000). Gluconacetobacter entanii sp. nov., isolated from submerged high-acid industrial vinegar fermentations. Int J Syst Bacteriol 50, 2013-2020.

Sokollek, S. J., Hertel, C. \& Hammes, W. P. (1998). Description of Acetobacter oboediens sp. nov. and Acetobacter pomorum sp. nov., two new species isolated from industrial vinegar fermentations. Int J Syst Bacteriol 48, 935-940.

Swings, J. (1992). The genera Acetobacter and Gluconobacter. In The Prokaryotes, pp. 2268-2286. Edited by A. Balows, H. G. Trüper, M. Dworkin, W. Harder \& K. H. Schleifer. New York: Springer.

Tindall, B. J. (1990a). A comparative study of the lipid composition of Halobacterium saccharovorum from various sources. Syst Appl Microbiol 13, 128-130.

Tindall, B. J. (1990b). Lipid composition of Halobacterium lacusprofundi. FEMS Microbiol Lett 66, 199-202. 
Toyosaki, H., Kojima, Y., Tsuchida, T., Hoshino, K.-I., Yamada, Y. \& Yoshinaga, F. (1995). The characterization of an acetic acid bacterium useful for producing bacterial cellulose in agitation cultures: the proposal of Acetobacter xylinum subsp. sucrofermentans subsp. nov. J Gen Appl Microbiol 41, 307-314.

Urakami, T., Tamaoka, J., Suzuki, K.-I. \& Komagata, K. (1989). Acidomonas gen. nov., incorporating Acetobacter methanolicus as Acidomonas methanolica comb. nov. Int J Syst Bacteriol 39, 50-55.

Willems, A., Doignon-Bourcier, F., Goris, J., Coopman, R., de Lajudie, P., De Vos, P. \& Gillis, M. (2001). DNA-DNA hybridization study of Bradyrhizobium strains. Int J Syst Evol Microbiol 51, 1315-1322.

Wilson, K. (1987). Preparation of genomic DNA from bacteria. In Current Protocols in Molecular Biology, pp. 2.4.1.-2.4.5. Edited by F. M. Ausubel, R. Brent, R. E. Kingston, D. D. Moore, J. G. Seidman, J. A. Smith \& K. Struhl. New York: Green Publishing and Wiley-Interscience.

Yamada, Y. (2000). Transfer of Acetobacter oboediens Sokollek et al. 1998 and Acetobacter intermedius Boesch et al. 1998 to the genus Gluconacetobacter as Gluconacetobacter oboediens comb. nov. and Gluconacetobacter intermedius comb. nov. Int J Syst Evol Microbiol 50, 2225-2227. 